\title{
INTERNATIONALIZATION PATHS OF CHINESE FIRMS: EVIDENCES FROM AN EMERGING ECONOMY
}

\author{
Saixing Zeng', Qi Shen², Chiming Tam³ ${ }^{3}$ Tianwei Wan ${ }^{4}$ \\ 1, 2, 4 Antai School of Economics \& Management, Shanghai Jiaotong University, \\ 535 Fahuazhen Road, Shanghai 200052, China \\ ${ }^{3}$ College of Science and Engineering, City University of Hong Kong, \\ 83 Tat Chee Avenue, Kowloon, Hong Kong \\ E-mail: '1zengsaixing@sjtu.edu.cn (correspondingauthor)
}

Received 9 September 2009; accepted 20 February 2010

\begin{abstract}
In this paper, an empirical study is conducted to explore the paths of internationalization for Chinese manufacturing firms. Correspondence analysis was employed to examine the relationship between the internationalization paths and the firms' form of ownership. It reveals that the internationalization paths of Chinese firms appear to be in a form of terrace structure, more firms adopting the rudimentary levels than the more matured courses of internalization. The findings indicate that Chinese firms are characterized by the relatively low levels of internationalization. Also the preferred destinations of going internationalization were identified for firms adopting outward foreign direct investments.
\end{abstract}

Keywords: internationalization; internationalization paths; outward foreign direct investment; emerging economy; China.

Reference to this paper should be made as follows: Zeng, S.; Shen, Q.; Tam, C.; Wan, T. 2010. Internationalization paths of Chinese firms: evidences from an emerging economy, Journal of Business Economics and Management 11(2): 297-315.

\section{Introduction}

As one of the most important strategies for firms looking for opportunities to achieve growth, internationalization has been extensively implemented by firms in advanced economies (Grundey 2007; Sapienza et al. 2006). The term "Internationalization" has been widely used to describe the outward movement of the international operations of a firm (Welch and Luostarinen 1988), which involves the process of adapting the firm's operations to cope with the strategy, structure and resources of international environments (Calof and Beamish 1995). Firms with higher level of internationalization will usually have higher penetration into overseas markets and/or in-depth cooperation with overseas companies (Zeng et al. 2009a).

With the rapid development of some emerging economies, many firms in these countries have begun to explore the foreign markets and go internationalization (Athreye and 
Kapur 2009; Bianchi and Ostale 2006; Mockaitis et al. 2006; Zeng et al. 2009a). The importance of key emerging economies (such as Brazil, China, South Africa, and India) as sources of outward foreign direct investments (FDI) among developing countries has increased over the past few years (Kumar 2008). In fact, the internationalization strategies of a firm are influenced by the economic environment including economic growth, competition, and labor prices (Amoako-Gyampah 2003). Comparing to their counterparts from advanced economies, firms in emerging economies have no advantages on their technological and size superiority (Zeng et al. 2008). Existing research on internationalization for firms from emerging economies suggests that the characteristics of these firms, their internationalization motives and ownership advantages are fundamentally different to those from developed countries (Buckley et al. 2007; Li 2007; Luo and Tung 2007). Undoubtedly the paths for internationalization are important for them to be successful in the business arena (Gemser et al. 2004; Mockaitis et al. 2006, 2007; Zhou et al. 2007).

With the increasing competition among local and foreign companies over the last decade, Chinese manufacturing firms have to explore foreign markets (Li 2007). A survey indicates that Chinese firms have become more active in foreign business activities (sales or assets), which grow very rapidly with an average annual growth rate of $21.3 \%$ (Fortanier and van Tulder 2009). Additionally, many scholars, business experts, and governmental agencies in China have enthusiastically encouraged the Chinese manufacturing firms to go internationalization, which however forms a major challenge for them (Zeng et al. 2008). As young firms venture into foreign markets, they have to face uncertainty and risks which entails a process of learning and adaptation ( $\mathrm{Lu}$ and Beamish 2001, 2004; Tan 2001; Zhou et al. 2007).

Although some literature has recorded extensive studies on internationalization of firms in developed countries, there is paucity, to our knowledge, of studies focused on the choice of paths in internationalization efforts of firms in developing countries. In this paper, an empirical study is conducted to explore the paths that the Chinese firms have adopted in internationalization, and their preferred destinations of outward FDI. The objective of this study is to provide a better understanding on how to go internationalization for firms in the emerging economies.

\section{Literature Review}

Firms in emerging economies will face various challenges when they internationalize in search of new markets. Cuervo-Cazurra et al. (2007) distinguished difficulties that were specific to a firm from those that are common to a set of firms. They argued that only a few of the resulting types of difficulties of internationalization were exclusive to the crossborder expansion, and proposed solutions that addressed the root cause of each type.

By examining relationships among market orientation, knowledge acquisition, and market commitment, and the direct and indirect effects of these variables on the performance of small and medium-sized enterprises in foreign markets, Armario et al. (2008) found that a direct positive relationship existed between market orientation and the 
strategy of internationalization, and that the effect of market orientation on performance in foreign markets was moderated by knowledge acquisition and market commitment. Camison and Villar (2009) examined the direct and indirect effects of ability to internationalize on propensity for cooperative internationalization. They found that capabilities were a positive predictor of propensity for cooperative internationalization, though this relationship was mediated by the adoption of a differentiating competitive strategy. In contrast, the propensity for international growth through alliances decreases as the firm's degree of involvement abroad increases.

The recent corporate evolution of China and India has been characterized by increased internationalization of firms in the form of significant OFDI flows and overseas mergers and acquisitions. Athreye and Kapur (2009) outlined the quantitative and qualitative patterns of internationalization activity of Chinese and Indian firms, identified factors that motivated these firms to invest overseas, and described the internationalization strategies they had adopted.

Using data from Taiwan, Chiao et al. (2008) examined, at the subsidiary level, the relationships between subsidiary size, internationalization, production diversification, and performance. They revealed that larger subsidiaries tended to engage in internationalization and product diversification activities to a greater degree, and, as a result, exhibiting superior performance; and subsidiaries that pursued outward internationalization and that reinvested in related businesses enjoyed enhanced performance.

Chittoor and Ray (2007) explored the internationalization paths of internationalizing firms in the Indian pharmaceutical industry. They revealed significant variation in their internationalization strategies. Chittoor and Ray (2007) proposed a conceptual model of internationalization for firms in emerging economies through a combination of exploitation and exploration strategies along the dimensions of products and markets. Firms that are able to supplement the conventional exploitation strategies with exploration through new products and new markets, by taking advantage of increasingly liberalized economies, could emerge as third-world multinationals with capabilities that could potentially challenge even multi-national corporations (MNCs) from the developed world.

Fortanier and van Tulder (2009) explored internationalization trajectories-patterns over time in the level, pace, variability, and temporal concentration of international expansion. They found that although internationalization trajectories of large and leading Chinese and Indian firms were indeed different, there were also considerable similarities between established developed country firms and new firms from emerging markets, not in the least, because they often interacted within the same sector.

By means of multiple case study research for Austrian and Hungarian companies, Reiner et al. (2008) found that process and product innovations, in addition to cost considerations, were becoming increasingly important dimensions in explaining the reasons for internationalization projects. The reasons for internationalization and solutions (relocated products and processes, entry mode and location) are closely interrelated.

Recent critiques of internationalization process models question the wisdom of delaying internationalization. Internationalizing late allows firms to assemble resources and 
gain experience but also allows inertia to develop. Sapienza et al. (2006) resolved this tension by positing that internationalization had differing effects on firms' survival and growth.

These effects are moderated by organizational age, managerial experience, and resource fungibility. Their framework provides insights into the evolution of capabilities across borders and may be tested and built on by organization researchers.

Integrating institution-, industry-, and resource-based views of internationalization, Yang et al. (2009) demonstrated that industrial characteristics, firms' resources, and institutional factors could significantly explain the differences and similarities of international expansion of Chinese and Japanese multinational enterprises (MNEs).

They illustrated the similarities and differences between Chinese and Japanese MNEs with two case studies: foreign direct investment (FDI) of Haier and Matsushita. Yang et al. (2009) suggested that how firms internationalized, in addition to being influenced by industry- and resource-based considerations, was inherently shaped by the domestic and international institutional frameworks governing these endeavors.

\section{Research Methodology}

\subsection{Correspondence analysis}

Correspondence analysis (CA) is one of the multivariate statistical analysis methods developed on the basis of $R$-type and $Q$-type Factor Analysis (Harcar and Spillan 2006; Shen et al. 2006). Correspondence analysis can eliminate complicated mathematical calculations and sub-processes, visually classifying samples on the factor loading map, and also marking out major classifying parameters (major factors) and basis, hence providing a direct, simple, and convenient multivariate statistical tool (Whipple 1994). The steps in applying CA are described in detail below.

Step 1: It assumes that the variable " $X$ " denotes the $n$ samples and each sample has an original data matrix with $k$ indicators.

$$
X=\left(\begin{array}{ccc}
x_{11} & \ldots & x_{1 k} \\
\vdots & \ddots & \vdots \\
x_{n 1} & \cdots & x_{n k}
\end{array}\right)
$$

Then, each element will be divided by the sum of all elements $T=\sum_{i=1}^{n} \sum_{j=1}^{k} x_{i k}$, and
obtain the following matrix:

$$
P=\left(p_{i j}\right)=\frac{1}{T}\left(x_{i j}\right)
$$


Step 2: The matrix is transformed and a new matrix is obtained as shown in equation (3):

$$
Z=\left(z_{i j}\right), \quad z_{i j}=\frac{p_{i j}-p_{i \bullet} p_{\bullet j}}{\sqrt{p_{i \bullet} p_{\bullet j}}}, \quad p_{i \bullet}=\sum_{j=1}^{k} p_{i j}, p_{\bullet j}=\sum_{i=1}^{n} p_{i j}
$$

Step 3: Component matrix of the $R$-factor is calculated. At first, the eigenvalue of $A=Z^{\prime} Z$ is calculated, and $\lambda_{1} \geq \lambda_{2} \geq \cdots \geq \lambda_{r}, 0 \leq r \leq \min (n, k)$.

Next, the corresponding eigenvectors $\mu_{1}, \mu_{2}, \cdots, \mu_{r}$ are normalized and the former $m$ eigenvalue and eigenvectors are extracted. Thus, the component matrix is obtained as shown in equation (4):

$$
F=\left(\sqrt{\lambda_{1}} \mu_{1}, \cdots, \sqrt{\lambda_{m}} \mu_{m}\right)
$$

Step 4: Component matrix of the $Q$-factor is calculated. At first, the eigenvectors of $B=Z Z^{\prime}$ are calculated. Next, the eigenvectors $v_{i}=Z \mu_{i}$ are normalized and the former $m$ eigenvalue and eigenvectors are extracted. Then, the component matrix is obtained as shown in equation (5):

$$
G=\left(\sqrt{\lambda_{1}} v_{1}, \cdots, \sqrt{\lambda_{m}} v_{m}\right)
$$

Step 5: Indicator plots and sample plots are depicted in plane axis of factors, of which the matrix $F$ is the coordinates of indicators plots and matrix $G$ is the coordinates of sample plots (Whipple 1994).

\subsection{Data collection and the sample}

The data were gathered via a cross-sectional survey using a questionnaire to a sample of manufacturing enterprises in China. In this investigation, 1,500 copies of questionnaires were distributed to the target subjects by either mailed or delivered personally.

A total of 569 valid questionnaires were collected from manufacturing enterprises in 16 cities of the metropolitan region of Yangtze Delta in China.

In terms of ownership, the surveyed firms were categorized including 68 Wholly Foreign-Owned Enterprises (WFOEs), 95 Joint Ventures (JVs), 130 State-Owned Enterprises (SOEs), 261 Private Enterprises (PEs) and 15 Collectively-Run Enterprises (CREs). Out of all the respondent firms, 157 firms employed over 2,001 people, 203 firms between 301 and 2,000, 172 firms between 300 and 51, and 37 firms below 50 . The study involves wider distribution of industries so that it can more fully reflect the characteristics of manufacturing enterprises at the Yangtze Delta region (Zeng et al. 2009a). 


\section{Results and Analysis}

\subsection{Selection of internationalization paths}

With respect to internationalization paths for manufacturing firms, Chittoor and Ray (2007) categorized them into: target markets, product profile, top management factors, trends in R\&D spending, manufacturing competence, and overseas mergers and acquisitions.

In this paper, internationalization paths are defined into five aspects, including "Export to a destination country (Exports)", "Grafting with foreign firms (Grafting)", "Technology transfer to foreign firms or technical cooperation (Technology transfer or technical cooperation)", "Outward foreign direct investment (Outward FDI)" and others.

Of all the respondent firms, 465 firms claimed that they adopted currently at least one path while the remaining 104 said none. In the survey, one respondent firm may have single or multiple internationalization paths. However, firms that adopted parallel paths in internationalization were limited. Of all the 465 firms in internationalization, 52 (11\%) have two paths; 7 firms $(2 \%)$ have three paths, while only one adopts four paths. Figure 1 shows the results of internationalization paths for the Chinese firms.

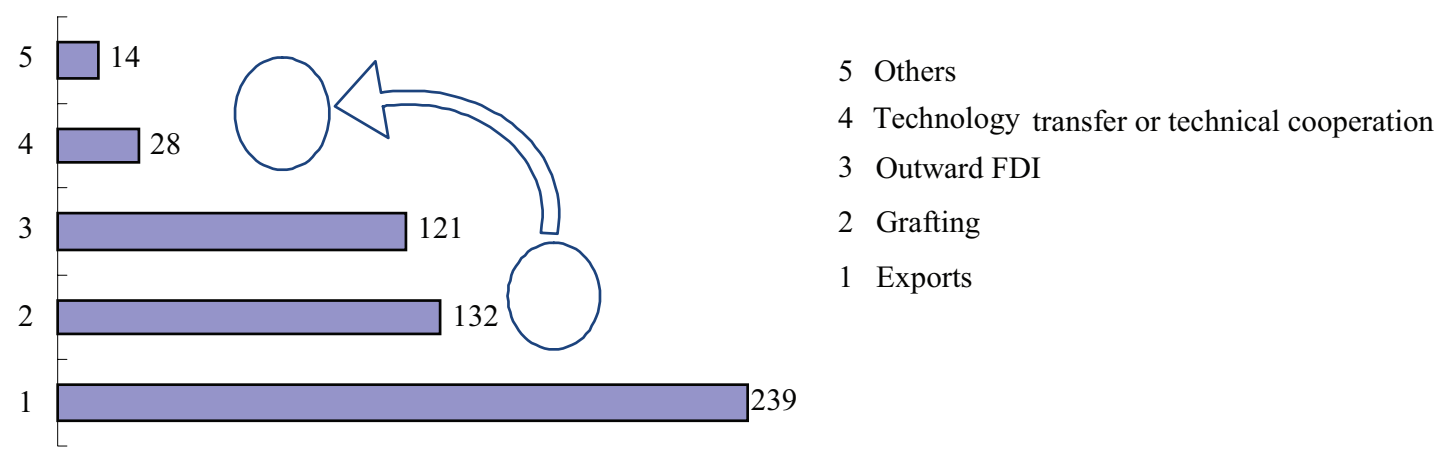

Fig. 1. Terrace structure of firm's internationalization paths

From Figure 1, it shows a terrace structure in term of frequency in adopting different internationalization paths for the Chinese manufacturing firms. It reveals that traditional product exports dominate the Chinese firms' internationalization efforts. However, "Technology transfer or technical cooperation" accounts for quite a small proportion.

With respect to the relationship between firms' internationalization paths and their ownership as well as their capital scale, Table 1 shows the frequencies of selection of internationalization paths for Chinese firms. The results of correspondence analysis between different ownerships and internationalization paths are shown in Table 2 and Figure 2. The results of corresponding analysis between different asserts scale and internationalization paths are shown in Table 3 and Figure 3. 


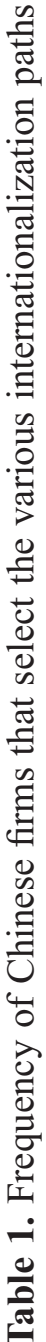

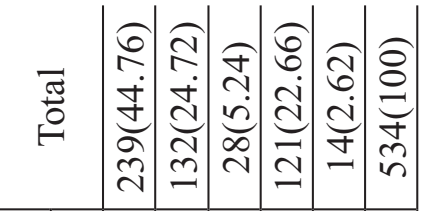

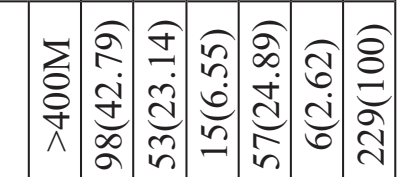

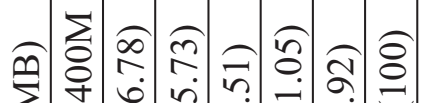

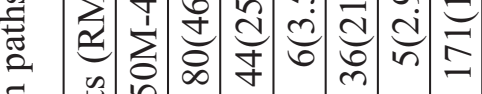$$
\text { . }
$$

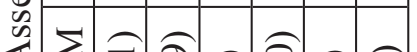

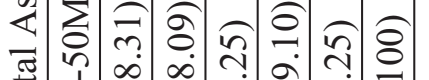$$
\text { • }
$$

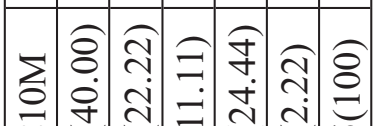

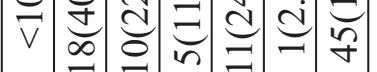

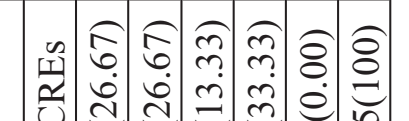$$
\text { 艺 }
$$$$
\text { ชิ ชิ ชิ }
$$$$
\text { nิ }
$$$$
\text { a }
$$$$
\text { 紋 }
$$

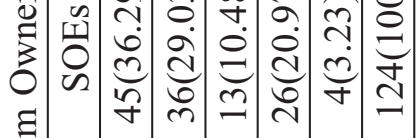$$
\text { 㱐 }
$$$$
\text { 踥 }
$$

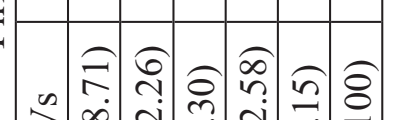

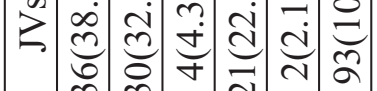

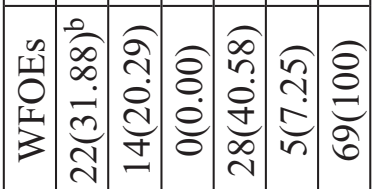

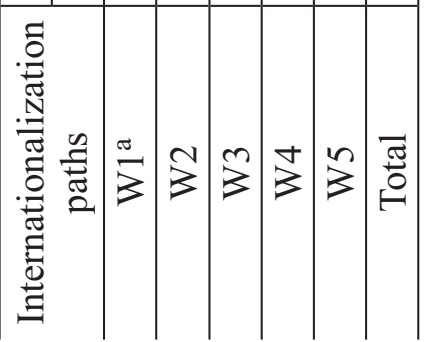

\begin{tabular}{|c|c|c|c|c|c|c|c|c|c|c|c|}
\hline $\begin{array}{l}0 \\
\frac{0}{0} \\
\frac{0}{2} \\
\frac{\pi}{\pi}\end{array}$ & 吾 & : & $\mid \begin{array}{c}\hat{n} \\
\infty \\
0\end{array}$ & $\begin{array}{l}\vec{n} \\
\grave{0}\end{array}$ & $\mid$ & $\begin{array}{l}\infty \\
0 \\
0 \\
0 \\
0 \\
0\end{array}$ & ڤ్ & $\begin{array}{l}\overrightarrow{1} \\
\infty \\
\dot{0}\end{array}$ & $\begin{array}{l}1 \\
\vdots \\
\vdots\end{array}$ & $\stackrel{\hat{\sigma}}{a}$ & $\mid \begin{array}{l}\infty \\
\infty \\
\infty \\
0 \\
0\end{array}$ \\
\hline 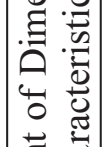 & $\sim$ & $\frac{m}{\tilde{\sigma}}$ & $\mid \begin{array}{l}2 \\
0 \\
0 \\
0\end{array}$ & $\mid \begin{array}{c}\hat{\sigma} \\
\hat{0} \\
0\end{array}$ & $\left.\mid \begin{array}{l}2 \\
0 \\
0 \\
0 \\
0\end{array}\right]$ & 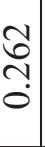 & 离 & $\mid \begin{array}{r}\tilde{2} \\
\dot{0}\end{array}$ & $\mid \begin{array}{l}\hat{\delta} \\
\infty \\
0 \\
0\end{array}$ & $\begin{array}{l}\text { D } \\
\stackrel{0}{0} \\
0\end{array}$ & $\begin{array}{l}\bar{n} \\
0 \\
0\end{array}$ \\
\hline$\frac{\infty}{\overrightarrow{0}}$ & - & 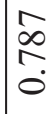 & 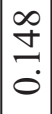 & 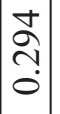 & $\mid \begin{array}{l} \pm \\
\vdots \\
0\end{array}$ & 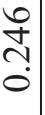 & $\begin{array}{l}\tilde{N} \\
\tilde{\sigma} \\
0\end{array}$ & $\mid \begin{array}{l}2 \\
0 \\
0\end{array}$ & $\begin{array}{l}n \\
0 \\
0 \\
0\end{array}$ & $\begin{array}{l}\hat{\alpha} \\
\infty \\
0\end{array}$ & $\begin{array}{c}\hat{n} \\
\infty \\
0 \\
0\end{array}$ \\
\hline
\end{tabular}

这

$\stackrel{n}{3}$

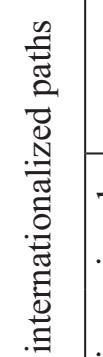

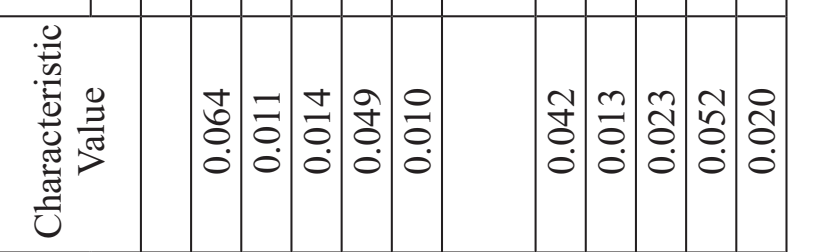

穴 葇

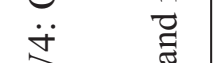

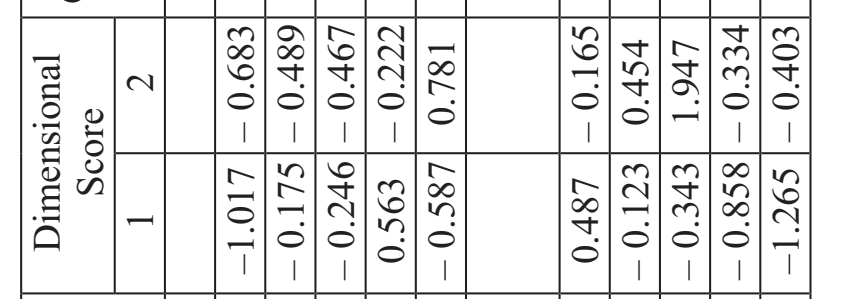

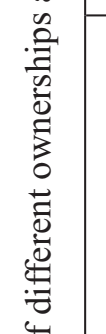

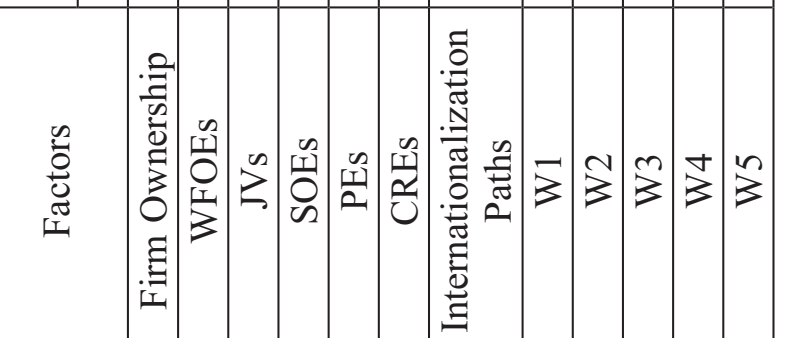
¿

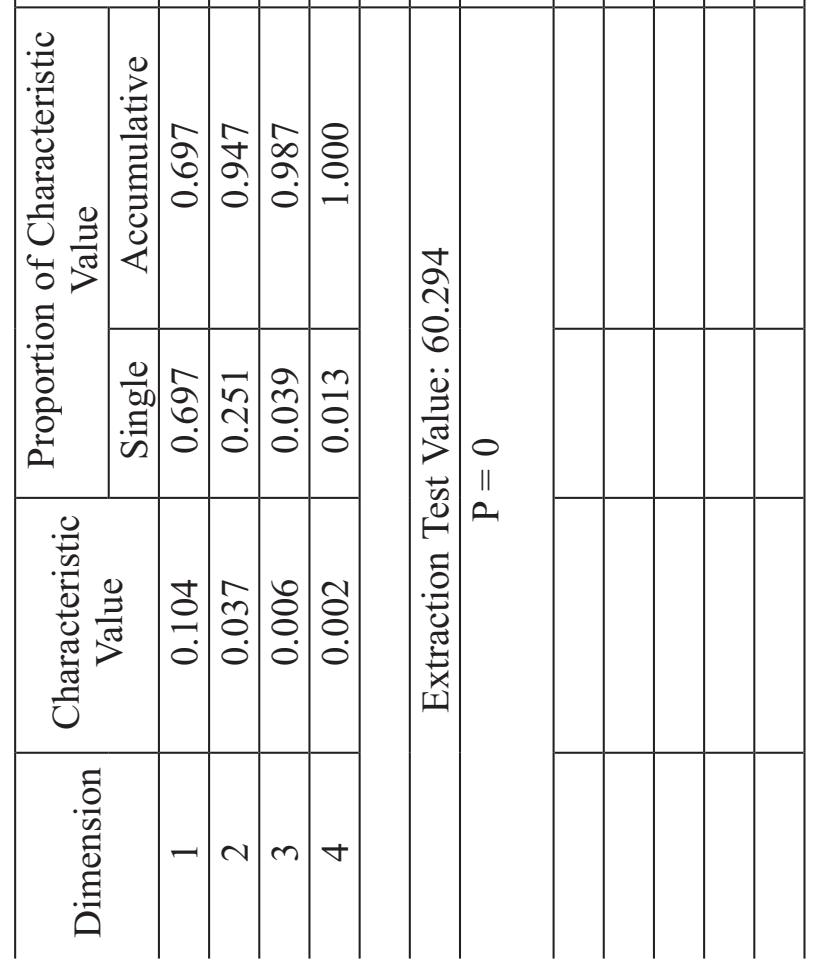


S. Zeng, Q. Shen, C. Tam, T. Wan. Internationalization paths of Chinese firms: evidences...

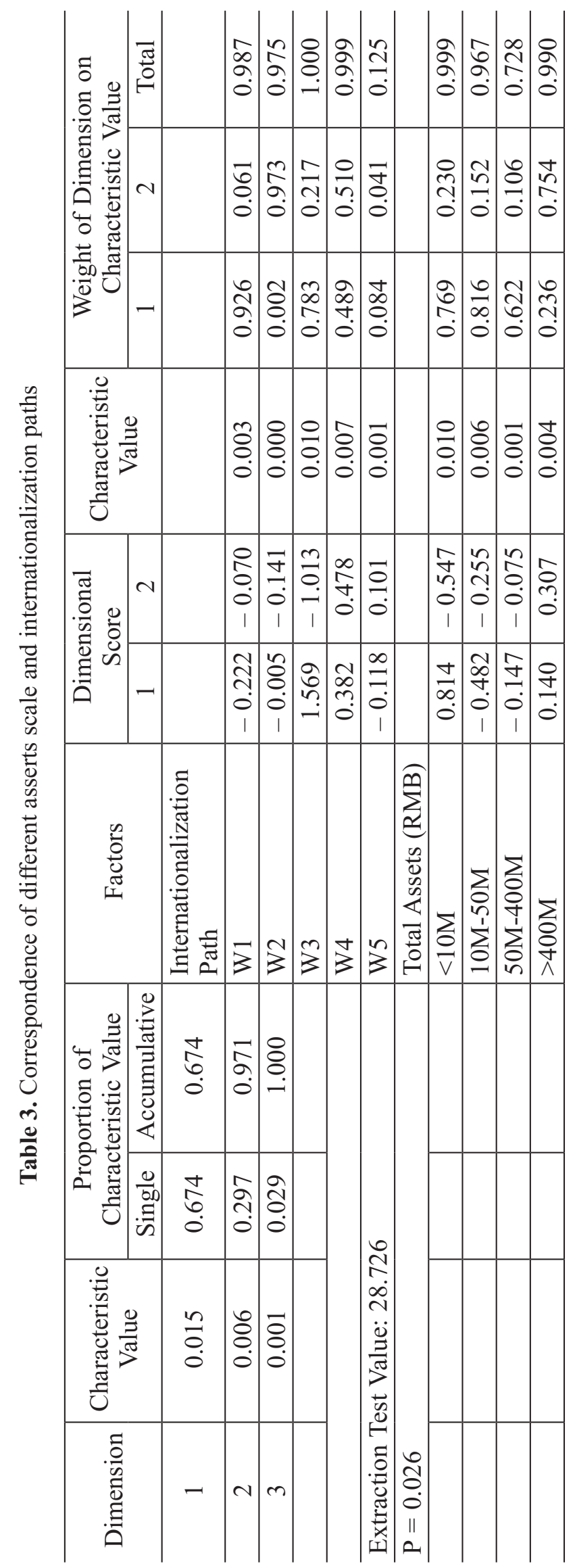




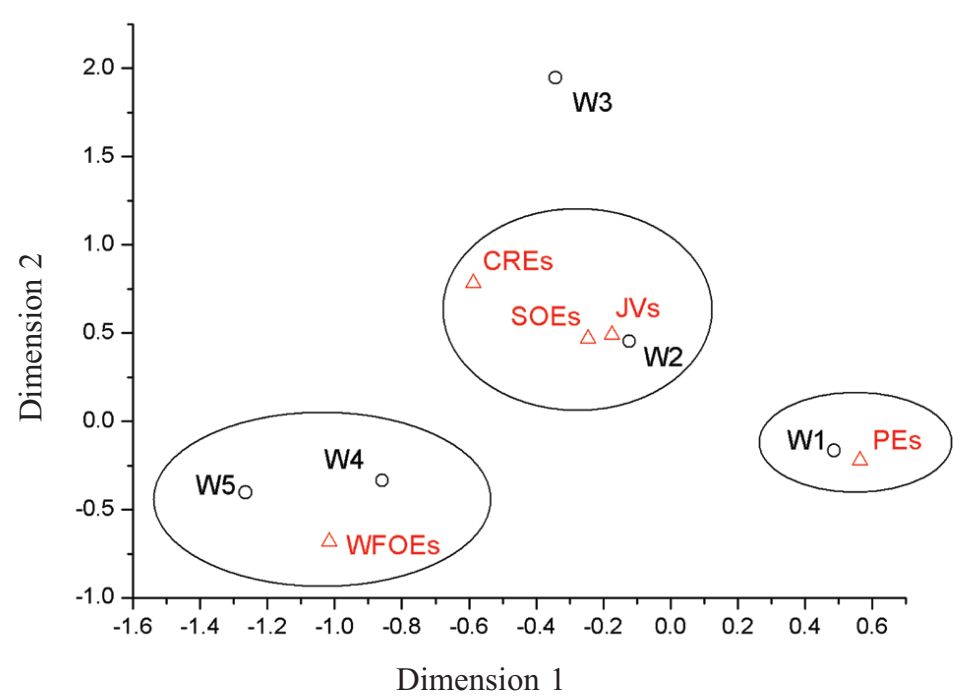

Fig. 2. Positioning maps between firms' ownership and internationalized paths

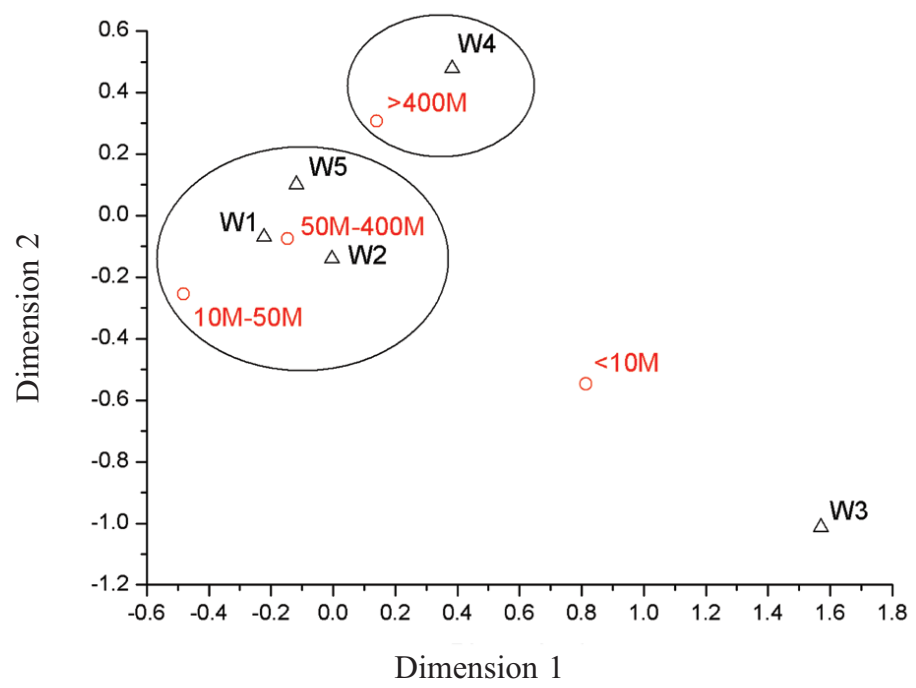

Fig. 3. Positioning maps between firms' scale and internationalized paths

\subsection{Analysis and Discussion}

\subsubsection{Exports and grafting}

Exports, as the first step in internationalization, are the simplest path for firms. Of all the respondent firms in this survey, half of them solely adopt exports as their internationalization path, revealing that Chinese firms are characterized by the relatively low levels of internationalization (Zeng et al. 2008), which was supported by Fortanier and 
van Tulder (2009). For those who have multiple paths for internationalization, most of them have taken the path of product exports. This means that product exports are the basic path of internationalization. Many firms develop other paths only after they have adopted product exports. When the export amount reaches a certain level and the firms have a specific overseas targeting market (Chittoor and Ray 2007), they will usually deepen their internationalization by some other courses, such as establishing overseas agencies or plants. Grafting with foreign firms has been regarded as one of traditional ways in internationalization. In the survey, 132 firms have made grafting with foreign firms to carry out internationalization. That shows that domestic cooperation with some foreign firms is an important way of internationalization for Chinese firms.

The fact that Chinese firms prefer the traditional internationalization paths could attribute to the following reasons: (1) Most of the respondent firms have limited resources (including human and information) to carry out the course of internationalization. In spite of the need for more intensive internationalization, limited resources result in the low level of internationalization for most Chinese firms (Yang et al. 2009); (2) The strange international market environment challenges the Chinese firms due to poor internationalization experience, especially for high level of internationalization, such as merger and acquisition. Hence it is easy for many Chinese firms to choose only the traditional path, which may minimize their risk (Zeng et al. 2009a).

\subsubsection{To implement outward FDI}

To implement outward FDI is an important step for firms to internationalize (Dumludag, 2009). Nowadays, some firms have started to implement outward FDI. Most of them are either WFOEs or with a total asset larger than 400 million RMB. WFOEs are familiar with the international market so they are more likely to implement outward FDI. PEs and SMEs are least likely to implement outward FDI as they are facing difficulties such as lack of capital, policy discrimination, information barriers, etc (Arranz and De Rroye 2009; Christophe and Lee 2005; Freeman et al. 2006).

\section{Investment Scale of outward FDI}

Table 4 lists investment scale of outward FDI for the surveyed firms.

Table 4. Investment scale of outward FDI for the past three years

\begin{tabular}{|c|c|c|c|c|c|c|c|c|c|c|}
\hline \multirow{2}{*}{$\begin{array}{c}\text { Accumulative } \\
\text { foreign } \\
\text { investment } \\
\text { in } 3 \text { years (USD) }\end{array}$} & \multicolumn{5}{|c|}{ Firm ownership } & \multicolumn{4}{|c|}{ Total Assets (RMB) } & \multirow[b]{2}{*}{ Total } \\
\hline & WFOEs & JVs & SOEs & PEs & CREs & $<10 \mathrm{M}$ & $10 \mathrm{M}-50 \mathrm{M}$ & $50 \mathrm{M}-400 \mathrm{M}$ & $>400 \mathrm{M}$ & \\
\hline$>\$ 10 \mathrm{M}$ & 11 & 6 & 8 & 3 & 0 & \begin{tabular}{|l|}
0 \\
\end{tabular} & 1 & 4 & 23 & 28 \\
\hline$\$ 5 \mathrm{M}-\$ 10 \mathrm{M}$ & 1 & 4 & 1 & 4 & 1 & 0 & 0 & 6 & 5 & 11 \\
\hline$\$ 1 \mathrm{M}-\$ 5 \mathrm{M}$ & 8 & 4 & 3 & 17 & 1 & 4 & 9 & 11 & 9 & 33 \\
\hline$<\$ 1 \mathrm{M}$ & 8 & 7 & 14 & 17 & 3 & 7 & 7 & 15 & 20 & 49 \\
\hline Total & 28 & 21 & 26 & 41 & 5 & 11 & 17 & 36 & 57 & 121 \\
\hline
\end{tabular}

Note: $1 \mathrm{USD}=6.827 \mathrm{RMB}$ 
From Table 4, it shows that only 28 firms have made outward FDI worth more than 10 million USD in the past three years, accounting for $23.14 \%$ of all the firms who have ever made outward FDI; 82 firms have made more than 5 million worth investment, accounting for $67.86 \%$. The average multinational investment amount is 6 million USD for developed countries and 4.5 million USD for developing countries, which shows that Chinese firms are still quite low in foreign investment scale (Buckley et al. 2007).

Selection of Investment Destination

The destinations of outward FDI for Chinese firms are shown in Table 5.

Table 5. Selection of destination for outward FDI

\begin{tabular}{c|l|l|l|l|l|l|l|l|l|l}
\hline \multirow{2}{*}{$\begin{array}{c}\text { Desti- } \\
\text { nation }\end{array}$} & \multicolumn{5}{|c|}{ Firm Ownership } & \multicolumn{4}{c|}{ Total Assets (RMB) } & \multirow{2}{*}{ Total } \\
\cline { 2 - 10 } & WFOEs & JVs & SOEs & PEs & CREs & $<10 \mathrm{M}$ & $10 \mathrm{M}-50 \mathrm{M}$ & $50 \mathrm{M}-400 \mathrm{M}$ & $>400 \mathrm{M}$ & \\
\hline O1 & $10(17.24)$ & $6(31.58)$ & $11(27.50)$ & $4(8.51)$ & $1(20.00)$ & $5(33.33)$ & $2(11.11)$ & $5(13.51)$ & $20(20.20)$ & $32(18.93)$ \\
\hline O2 & $12(20.69)$ & $8(42.11)$ & $11(27.50)$ & $10(21.28)$ & $0(0.00)$ & $4(26.67)$ & $0(0.00)$ & $10(27.03)$ & $27(27.27)$ & $41(24.26)$ \\
\hline O3 & $5(8.62)$ & $0(0.00)$ & $2(5.00)$ & $3(6.38)$ & $0(0.00)$ & $2(13.33)$ & $0(0.00)$ & $0(0.00)$ & $8(8.08)$ & $10(5.92)$ \\
\hline O4 & $9(15.52)$ & $1(5.26)$ & $6(15.00)$ & $16(34.04)$ & $1(20.00)$ & $2(13.33)$ & $9(50.00)$ & $9(24.32)$ & $13(13.13)$ & $33(19.53)$ \\
\hline O5 & $8(13.79)$ & $2(10.53)$ & $1(2.50)$ & $4(8.51)$ & $1(20.00)$ & $0(0.00)$ & $1(5.56)$ & $6(16.22)$ & $9(9.09)$ & $16(9.47)$ \\
\hline O6 & $7(12.07)$ & $1(5.26)$ & $4(10.00)$ & $4(8.51)$ & $2(40.00)$ & $2(13.33)$ & $3(16.67)$ & $2(5.41)$ & $11(11.11)$ & $18(10.65)$ \\
\hline O7 & $7(12.07)$ & $0(0.00)$ & $4(10.00)$ & $3(6.38)$ & $0(0.00)$ & $0(0.00)$ & $2(11.11)$ & $2(5.41)$ & $10(10.10)$ & $14(8.28)$ \\
\hline O8 & $0(0.00)$ & $1(5.26)$ & $1(2.50)$ & $3(6.38)$ & $0(0.00)$ & $0(0.00)$ & $1(5.56)$ & $3(8.11)$ & $1(1.01)$ & $5(2.96)$ \\
\hline Total & $58(100)$ & $19(100)$ & $40(100$ & $47(100)$ & $5(100)$ & $15(100)$ & $18(100)$ & $37(100)$ & $99(100)$ & $169(100)$ \\
\hline
\end{tabular}

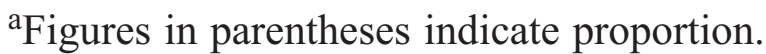

Note: O1: Hong Kong, Macao and Taiwan; O2: Europe and America or Japan; O3: Australia;

O4: South East Asia; O5: Mid or East Europe or Russia; O6: Middle East or centre Asia; O7: Africa or South America; O8: Others

From Table 5, it indicates that Europe (and America or Japan), South East Asia, and Hong Kong, Macao and Taiwan are ranked top three most preferred destinations of outward FDI for Chinese firms.

In practice, Hong Kong, Macao and Taiwan, having similar culture, custom and environments, etc. should have been the most favorable destination for the Chinese firms. However, Europe (and America or Japan), which is remote in mental and physical distance to Chinese firms, has been the most popular destination of those firms. Contrary to the mental distance explanation, Chinese firms' preference for the European (and American or Japanese) market may be a result of mental adoration.

Table 5 indicates that WFOEs have a wide variety of investment destination markets, attributing to their abundant capital and managerial expertise in the international market. Though Europe and America or Japan, South East Asia and Hong Kong, Macao and Taiwan are their main destinations of outward FDI, they are not limited to these areas. In other words, they are less affected by the mental adoration when making investment decisions, as WFOEs are actually coming from developed countries such as Europe 
and America or Japan. The decision makers are familiar with the developed countries' markets and have already established their firms' reputation (Brock and Urbonavicius, 2008; Pazienza and Vecchione, 2009).

In contrast to WFOEs, JVs and SOEs are more affected by the mental adoration when they are making decisions for outward FDI. Despite the fierce competition and high risk of failure in developed countries' markets, these firms hope to quickly raise the popularity of the products of the firms and raise their reputation (Duysters et al. 2009; Westhead et al. 2001).

For PEs, as they are limited in capital, so they are more likely to adopt a low risk and stable developmental internationalization paths. Most of them focus on the South East Asia areas. Results on the destination of outward FDI and enterprise ownership are shown in Figure 4.

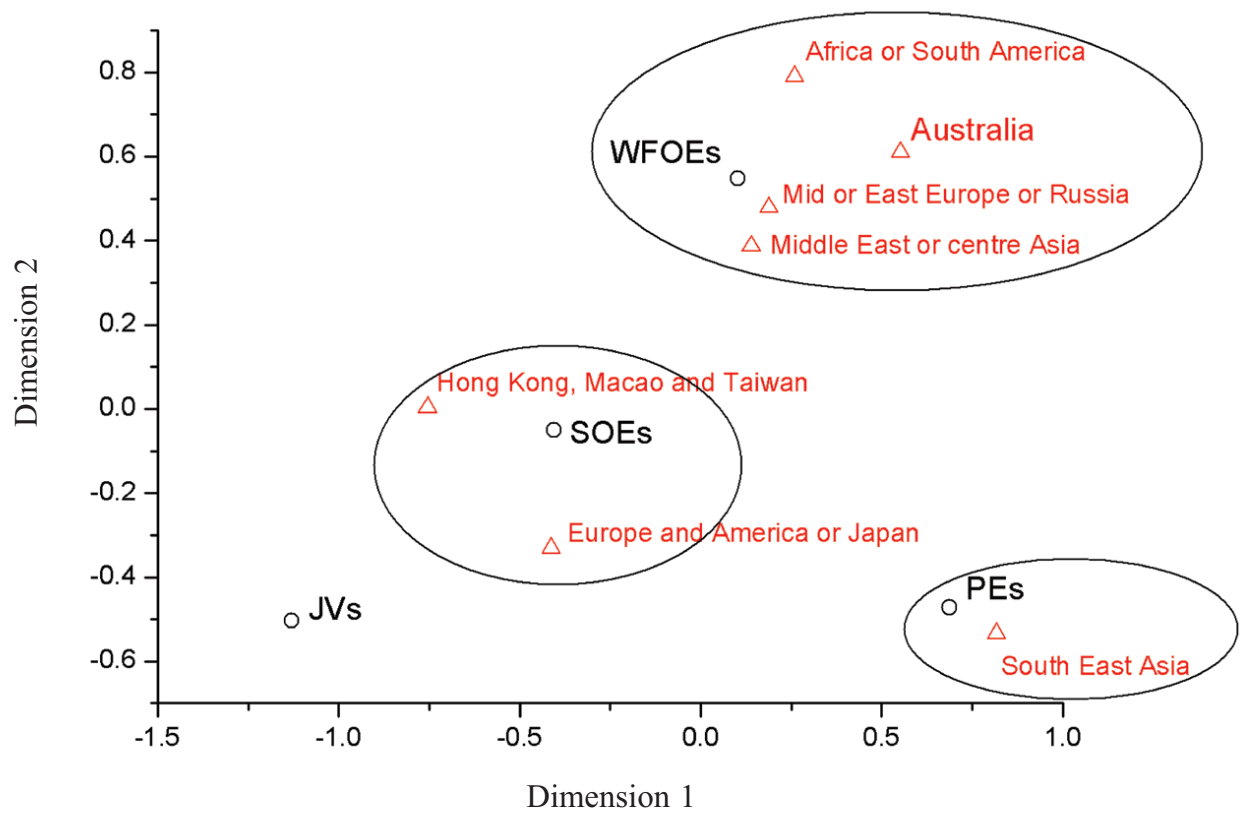

Fig. 4. Positioning maps between destination and enterprise ownership

With respect to the relationship between destination and total asset scale, most firms which have a total asset larger than 50 million RMB are significantly affected by this mental adoration. Many of them take the risk to invest in developed markets when their anti-risk capabilities are enhanced with the increase in their total asset (Tvaronaviciene et al. 2008). For firms with a total asset over 400 million RMB, their investment locations are most diversified and with few limitations. With the strong anti-risk capability and already established reputation, their choices of foreign direct investments are mostly profit-driven instead of governed by mental adoration. For the remaining firms with a total asset between 10 million to 50 million RMB, they mostly focus on the South-East Asia areas. Results between destination and enterprise scale are shown in Figure 5. 


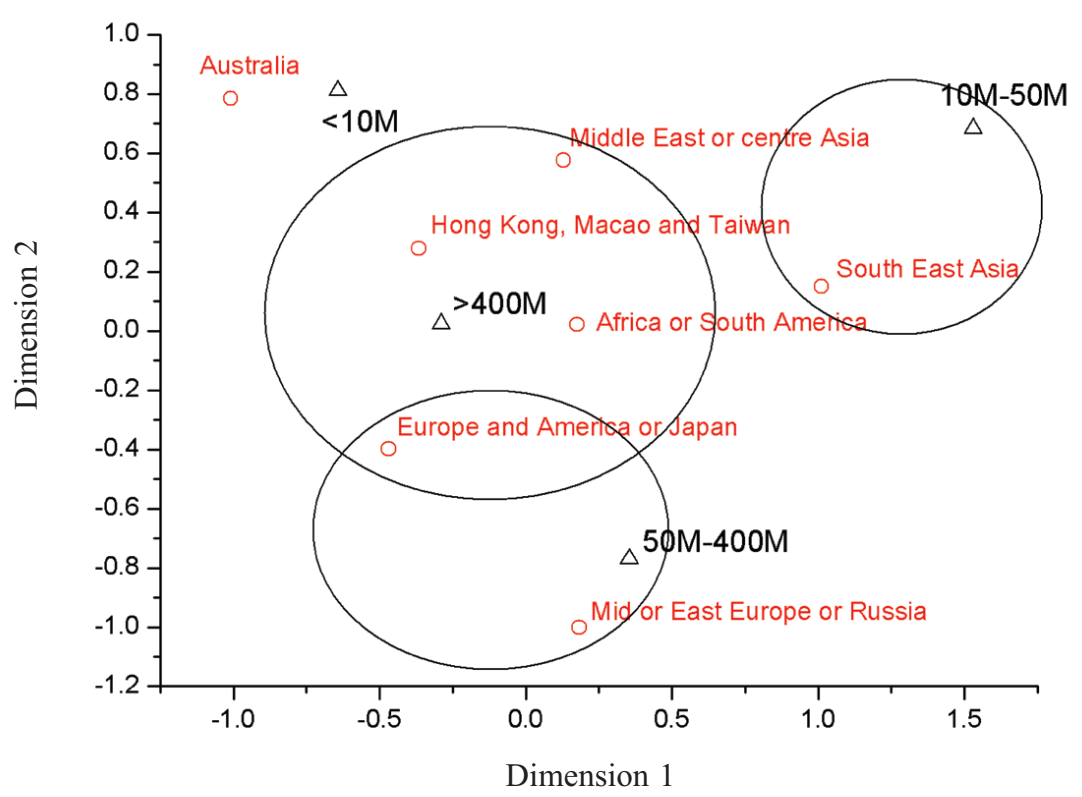

Fig. 5. Positioning maps between destination and enterprise scale (Total assets in RMB)

\section{Investment Sectors}

Table 6 shows the sectors of outward FDI for Chinese firms. From Table 6, it reveals that the majority of surveyed firms will produce exactly the same products when their outward FDIs are also in the manufacturing industry. Some of them may produce not exact but of similar type products. Meanwhile, a few will invest in non-manufacturing industries.

Table 6. Sector of outward FDI

\begin{tabular}{l|c|c|c|c|c|c|c|c|c|c}
\hline \multirow{2}{*}{ Investment Sectors } & \multicolumn{5}{|c|}{ Firm Ownership } & \multicolumn{5}{c}{ Total Assets (RMB) } \\
\cline { 2 - 15 } & WFOEs & JVs & SOEs & PEs & CREs & $<10 \mathrm{M}$ & $10 \mathrm{M}-50 \mathrm{M}$ & $50 \mathrm{M}-400 \mathrm{M}$ & $>400 \mathrm{M}$ & Total \\
\hline The same products & 17 & 9 & 10 & 23 & 3 & 5 & 6 & 25 & 26 & 62 \\
\hline Different products & 5 & 4 & 2 & 6 & 2 & 2 & 4 & 3 & 10 & 19 \\
\hline Different manufacturing & 0 & 0 & 2 & 0 & 0 & 0 & 0 & 1 & 1 & 2 \\
\hline Non- manufacturing & 4 & 1 & 9 & 5 & 0 & 2 & 4 & 3 & 10 & 19 \\
\hline Others & 0 & 1 & 1 & 1 & 0 & 0 & 0 & 0 & 3 & 3 \\
\hline Total & 26 & 15 & 24 & 35 & 5 & 9 & 14 & 32 & 50 & 105 \\
\hline
\end{tabular}

Outward FDI for producing exactly the same products with the parent company will have more chance to succeed and enjoy higher profits, so most firms chose that. Some of them may have to change a little bit of their parent company's products in order to conform to local regulations or demands, which results in the not exact but of similar type products. Investing in non-manufacturing industries is mostly for the purpose of merger and acquisition in the future, by which they can get the technology, information and market channels. But if the purpose of direct investment is to gain a higher reputa- 
tion in the market of the home country, these kinds of non-manufacturing investment are of high risk, non-direct profitable and more likely to be for the mental adoration. Results between sectors of outward FDI and enterprise ownership are shown in Figure 6.

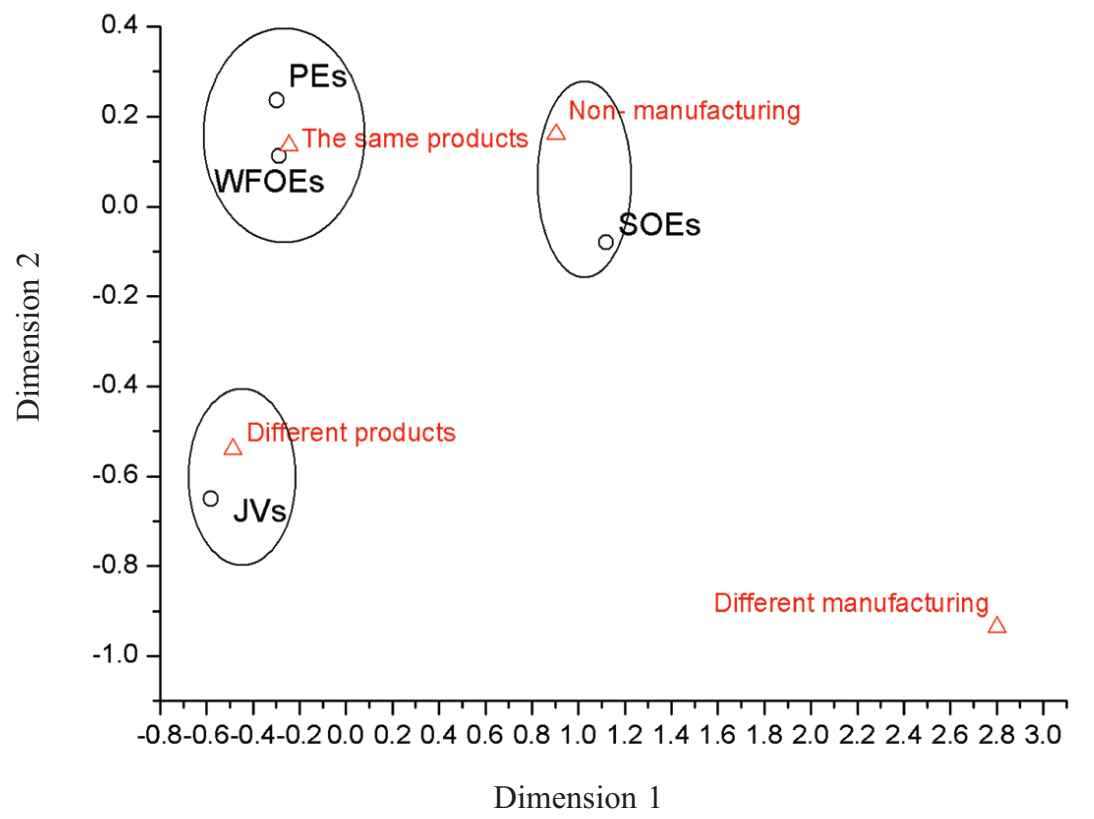

Fig. 6. Positioning maps between investment sector and enterprise ownership

PEs and WFOEs mainly invest in the same products as their parent companies. Some of SOEs invest in non-manufacturing industries. This is attributed to the fact that SOEs are mostly affected by mental adoration. They are willing to make these high risk investments to promote a quicker market spread as they are strong in risk-taking capabilities. Some manufacturing companies, such as Nanjing Auto, are beginning to make acquisitions for technology and brands (Hagiwara 2006; Kumar 2008).

\subsubsection{Technology transfer or technical cooperation}

The low proportion of technology transfer to foreign firms may result from the fact that most Chinese manufacturing firms generally face more uncertainties and barriers to technology innovation, which hindered them from promoting innovative capability and developing new technologies (Zeng et al., 2009b, 2010). Under such circumstances, the Chinese firms, in general, do not have capability to implement technology transfer to foreign firms (Zeng et al., 2008).

\section{Conclusion}

In recent years, Chinese manufacturing firms have to explore foreign markets and to go internationalization. As young firms venture into foreign markets, they have to face 
uncertainty and risks which entails a process of learning and adaptation. The paths for internationalization are important for them to be successful in the process. In this paper, an empirical study is conducted to explore the paths for the Chinese firms in internationalization. The structure of adopting different internationalization paths was examined for the Chinese manufacturing firms. Traditional product exports dominate the Chinese firms' internationalization efforts, which reveal that the Chinese firms would be characterized by relatively low levels of internationalization. Chinese firms prefer the traditional internationalization paths, which could attribute to the fact that: (1) Most of the respondent firms have limited resources (including human and information) to carry out the course of internationalization. (2) The uncertain international market environment challenges the Chinese firms due to poor internationalization experience, especially for high level of internationalization, such as merger and acquisition.

Meanwhile, outward FDI was explored by some Chinese firms. With respect to locations of outward FDI, it is found that Europe (and America or Japan), South East Asia, and Hong Kong, Macao and Taiwan are ranked top three most preferred destinations. Hong Kong, Macao and Taiwan, having similar culture, custom and environments, etc. should have been the most favorable destinations for the Chinese firms. In practice, Europe (and America or Japan), which is remote in mental and physical distance to Chinese firms, has been the most popular destination of those firms. Contrary to the mental distance explanation, Chinese firms' preference for the European (and American or Japanese) market may be a result of mental adoration.

Comparatively, technology transfer to foreign firms, at higher internationalization level, is least adopted by Chinese firms, which highlights that they are still weak in technology innovation for promoting innovative capability and developing new technologies.

\section{Acknowledgements}

The authors gratefully acknowledge the very helpful comments and suggestions given by two anonymous referees. The authors gratefully acknowledge the respondents who contributed to this research. This study is supported by the National Natural Science Foundation of China (No.70540001, 70772067), the Ministry of Education of China (20090073110029, NCET-06410), and the Shuguang Planning of Shanghai Education Development Foundation.

\section{References}

Amoako-Gyampah, K. 2003. The relationships among selected business environment factors and manufacturing strategy: insights from an emerging economy, Omega - The International Journal of Management Science 31(4): 287-301. doi:10.1016/S0305-0483(03)00049-5

Armario, J. M.; Ruiz, D. M.; Armario, E. M. 2008. Market orientation and internationalization in small and medium-sized enterprises, Journal of Small Business Management 46(4): 485-511. doi:10.1111/j.1540-627X.2008.00253.X

Arranz, N.; De Rroye, J. C. F. 2009. Internationalization process of Spanish small firms strategies, transactions and barriers, International Small Business Journal 27(4): 420-441. doi:10.1177/0266242609334968 
S. Zeng, Q. Shen, C. Tam, T. Wan. Internationalization paths of Chinese firms: evidences...

Athreye, S.; Kapur, S. 2009. Introduction: The internationalization of Chinese and Indian firms trends, motivations and strategy, Industrial and Corporate Change 18(2): 209-221. doi:10.1093/icc/dtp007

Bianchi, C.C.; Ostale, E. 2006. Lessons learned from unsuccessful internationalization attempts: Examples of multinational retails in Chile, Journal of Business Research 59(1): 140-147.

doi:10.1016/j.jbusres.2005.01.002

Brock, G.; Urbonavicius, S. 2008. Regional FDI growth in Lithuania, 1996-2003, Transformations in Business \& Economics 7(1): 80-88.

Buckley, P. J.; Clegg, C. A.; Liu, X.; Voss, H.; Zheng, P. 2007. The determinants of Chinese outward foreign direct investment, Journal of International Business Studies 38(4): 499-518. doi:10.1057/palgrave.jibs.8400277

Calof, J. L.; Beamish, P. W. 1995. Adapting to foreign markets: explaining internationalization, International Business Review 4(2): 115-131. doi:10.1016/0969-5931(95)00001-G

Camison, C.; Villar, A. 2009. Capabilities and propensity for cooperative internationalization, International Marketing Review 26(2): 124-150. doi:10.1108/02651330910950394

Chiao, Y. C.; Yu, C. M. J.; Li, P. Y.; Chen, Y. C. 2008. Subsidiary size, internationalization, product diversification, and performance in an emerging market, International Marketing Review 25(6): 612-633. doi:10.1108/02651330810915556

Chittoor, R.; Ray, S. 2007. Internationalization paths of Indian pharmaceutical firms-A strategic group analysis, Journal of International Management 13(3): 338-355. doi:10.1016/j.intman.2007.05.008

Christophe, S.E.; Lee, H. 2005. What matters about internationalization: a market-based assessment, Journal of Business Research 58(5): 636-643. doi:10.1016/j.jbusres.2003.08.010

Cuervo-Cazurra, A.; Maloney, M. M.; Manrakhan, S. 2007. Causes of the difficulties in internationalization, Journal of International Business Studies 38(5): 709-725.

doi:10.1057/palgrave.jibs. 8400295

Dumludag, D. 2009. An analysis of the determinants of foreign direct investment in Turkey: The role of the institutional context, Journal of Business Economics and Management 10(1): 15-30. doi:10.3846/1611-1699.2009.10.15-30

Duysters, G.; Jacob, J.; Lemmens, C.; Yu, J. 2009. Internationalization and technological catching up of emerging multinationals: a comparative case study of China's hair group, Industrial and Corporate Change 18(2): 325-349. doi:10.1093/icc/dtp006

Fortanier, F.; van Tulder, R. 2009. Internationalization trajectories-a cross-country comparison: Are large Chinese and Indian companies different? Industrial and Corporate Change 18(2): 223-247. doi:10.1093/icc/dtp003

Freeman, S.; Edwards, R.; Schroder, B. 2006. How smaller born-global firms use networks and alliances to overcome constraints to rapid internationalization, Journal of International Marketing 14(3): 33-63. doi:10.1509/jimk.14.3.33

Gemser, G.; Brand, M.J.; Sogre, A. 2004. Exploring the internationalization process of small businesses: A study of Dutch old and new economy firms, Management International Review 44(2): $127-150$.

Grundey, D. 2007. Internationalization of markets: The internationalization process of Danish companies in Lithuania, Transformations in Business \& Economics 6(1): 85-108.

Hagiwara, Y. 2006. Outward investment by China gathering stream under the go global strategy, Economic Review Tokyo: Bank of Tokyo-Mitsubishi UFJ 1(17): 1-6.

Harcar, T.; Spillan, J. E. 2006. Exploring Latin American family decision-making using correspondence analysis, Journal of World Business 41(3): 221-232. doi:10.1016/j.jwb.2006.01.009

Kumar, N. 2008. Internationalization of Indian enterprises: patterns, strategies, ownership advantages, and implications, Asian Economic Policy Review 3(2): 242-261.

doi:10.1111/j.1748-3131.2008.00109.x 
Li, P. 2007. Towards an integrated theory of multinational evolution: the evidence of Chinese multinational enterprises as latecomers, Journal of International Management 13(3): 296-318. doi:10.1016/j.intman.2007.05.004

Lu, J. W.; Beamish, P. W. 2001. The internationalization and performance of SMEs, Strategic Management Journal 22(6-7): 565-586. doi:10.1002/smj.184

Lu, J. W.; Beamish, P. W. 2004. International diversification and firm performance: the S-curve hypothesis, Academy of Management Journal 47(4): 598-609. doi:10.2307/20159604

Luo, Y.; Tung, R. 2007. International expansion of emerging market enterprises: a springboard perspective, Journal of International Business Studies 38(4): 481-498. doi:10.1057/palgrave.jibs.8400275

Mockaitis, A. I.; Giedraitis, V.; Vaiginienè, E. 2007. How active are Lithuanian manufacturing SMEs in international markets? some preliminary findings, Transformations in Business \& Economics 6(1): 109-121.

Mockaitis, A. I.; Vaiginienè, E; Giedraitis, V. 2006. The internatioanlization efforts of Lithuanian manufacturing firms-strategy or luck? Research in International Business and Finance 20(1): 111-126. doi:10.1016/j.ribaf.2005.02.001

Pazienza, P.; Vecchione, V. 2009. Preliminary investigation of the determinants of FDI distribution in Italy, Journal of Business Economics and Management 10(2): 99-107. doi:10.3846/1611-1699.2009.10.99-107

Reiner, G.; Demeter, K.; Poiger, M.; Jenei, I. 2008. The internationalization process in companies located at the borders of emerging and developed countries, International Journal of Operations \& Production Management 28(9-10): 918-940. doi:10.1108/01443570810903096

Sapienza, H. J.; Autio, E.; George, G.; Zahra, S. A. 2006. A capabilities perspective on the effects of early internationalization on firm survival and growth, Academy of Management Review 31(4): 914-933. doi:10.2307/20159258

Shen, X. X.; Li, D. M.; Shen, C. 2006. Evaluating China's university library web sites using correspondence analysis, Journal of the American Society for Information Science and Technology 57(4): 493-500. doi:10.1002/asi.20288

Tan, J. 2001. Innovation and risk-taking in a transitional economy: a comparative study of Chinese managers and entrepreneurs, Journal of Business Venturing 16(4): 359-376.

doi:10.1016/S0883-9026(99)00056-7

Tvaronaviciene, M.; Grybaite, V.; Korsakienè, R. 2008. Foreign capital destinations: Baltic States Versus India, Journal of Business Economics and Management 9(3): 227-234. doi:10.3846/1611-1699.2008.9.227-234

Westhead, P.; Wright, M.; Ucbasaran, D.; Martin, F. 2001. International market selection strategies of manufacturing and services firms, Entrepreneurship and Regional Development 13(1): 17-46. doi:10.1080/089856201750046793

Welch, L.; Luostarinen, R. 1988. Internationalization - evolution of a concept, Journal of General Management 14(2): 34-56.

Whipple, T.W. 1994. Mapping focus group data, Marketing Research 6(1): 16-21.

Yang, X. H.; Jiang, Y.; Kang, R. P.; Ke, Y. B. 2009. A comparative analysis of the internationalization of Chinese and Japanese firms, Asia Pacific Journal of Management 26(1): 141-162. doi:10.1007/s10490-007-9065-0

Zeng S. X.; Xie, X. M.; Tam, C. M. 2010. Relationship between cooperation networks and innovation performance of SMEs, Technovation 30(3): 181-194. doi:10.1016/j.technovation.2009.08.003

Zeng, S. X.; Xie, X. M.; Tam, C. M.; Wan, T. W. 2009a. Relationships between business factors and performance in internationalization: An empirical study in China, Management Decision 47(2): 308-329. doi:10.1108/00251740910938939

Zeng, S. X.; Xie, X. M.; Tam, C. M.; Sun, P. M. 2009b. Identifying cultural difference in R\&D project 
for performance improvement: a field study, Journal of Business Economics and Management 10(1): 61-70. doi:10.3846/1611-1699.2009.10.61-70

Zeng, S. X.; Xie, X. M.; Tam, C. M.; Wan, T. W. 2008. Competitive priorities of manufacturing firms for internationalization: An empirical research, Measuring Business Excellence 12(3): 44-55. doi:10.1108/13683040810900395

Zhou, L. X.; Wu, W. P.; Luo, X. M. 2007. Internationalization and the performance of born-global SMEs: the mediating role of social networks, Journal of International Business Studies 38(4): 673690. doi:10.1057/palgrave.jibs. 8400282

\title{
KINIJOS İMONIŲ INTERNACIONALIZAVIMO BŪDAI: TAM TIKRI AUGANČIOS EKONOMIKOS BRUOŽAI
}

\author{
S. Zeng, Q. Shen, C. Tam, T. Wan
}

Santrauka

Straipsnyje pateiktas empirinis tyrimas, atliktas siekiant išsiaiškinti internacionalizavimo būdus Kinijos gamybos įmonèse. Norint ištirti ryšį tarp internacionalizavimo būdų ir įmonès nuosavybès formos, buvo pritaikyta atitikties analizè. Ji parodè, kad internacionalizavimo būdai Kinijos įmonèse yra pylimo formos, t. y. dauguma imonių diegia pradinio, be ne brandesnio lygmens internacionalizavimo būdą. Atskleista, kad Kinijos imonėse internacionalizavimo lygis yra gana žemas. Nustatytas pageidautinas internacionalizavimo tikslas - išorinių tiesioginių užsienio investicijų naudojimas.

Reikšminiai žodžiai: internacionalizavimo, internacionalizavimo būdai, išorinės tiesioginès užsienio investicijos, auganti ekonomika, Kinija.

Saixing ZENG. Professor works in the Antai School of Economics \& Management, Shanghai Jiaotong University, China. He received his Ph. D degree in management from Harbin Institute of Technology, China. As a research fellow, he worked at City University of Hong Kong for several times. As a researcher in technology management and related fields, he has managed a large number of research projects, and has published more than 120 journal and conference papers, books, and reports on technology management and project management, such as in Technovation, Management Decision, Journal of Management in Engineering, Journal of Cleaner Production, Computers \& Industrial Engineering, Managerial Auditing Journal, and International Journal of Quality \& Reliability Management etc. $\mathrm{He}$ also teaches extensively in this field at both postgraduate and degree levels, and has successfully supervised a number of $\mathrm{PhD}$ and MSc students. Currently he is the Head of Department of Management Science and Director of Institute of System Engineering at Shanghai Jiaotong University, China. He acts as reviewers for more than ten international journals.

Qi SHEN. Mr. is a Research Assistant, in the Antai School of Economics \& Management, Shanghai Jiaotong University, China. His research area focuses on firm's internationalization. He involved in several research projects from National Natural Science Foundation of China and the Ministry of Education of China.

Chiming TAM. Professor has been teaching at the City Unoversity of Hong Kong since 1986. In 1984, he took a Master of Science in Loughborough University, UK. After returning from, he worked as a project manager. He had participated in some of the earliest Hong Kong invested projects in hotels and factories in the PRC. He obtained a PhD in the same university in 1993. He has been as leaders of several teaching programs and successfully supervised a number of $\mathrm{PhD}$ and MSc students.

As an active researcher in international project management, Professor Tam has published more than 150 international refereed journal papers in International Journal of Project Management, Journal of Management in Engineering etc. 
Tianwei WAN. Dr. is a Research Fellow, in the Antai School of Economics \& Management, Shanghai Jiaotong University, China. He received his $\mathrm{Ph}$. D degree in management from the same university. His research area focuses on FDI spillover and firm's internationalization. He involved in several research projects from National Natural Science Foundation of China and Research Center of Metropolis Development \& Management of China. Dr. Wan has published more than 10 articles. 